\title{
Paraolimpíada Sidney 2000
}

Inicialmente gostaria de agradecer esta oportunidade ofertada pela Revista Brasileira de Medicina do Esporte (RBME), em propiciar, nesse número especial, a divulgação de todo o trabalho técnico/científico que foi desenvolvido junto aos atletas paraolímpicos brasileiros.

Acredito que, ter coordenado toda essa equipe de excelentes profissionais e de diversas instituições de ensino e pesquisa de todo o país, foi um grande privilégio e que com certeza trouxe muitos frutos para o crescimento do Desporto Paraolímpico Nacional.

No entanto, não posso deixar de agradecer ao Comitê Paraolímpico Brasileiro (CPB), em nome do atual presidente Sr. Vital Severino Neto e de seu antecessor, Sr. João Batista Carvalho e Silva que oportunizou e continuam oportunizando o desenvolvimento de um trabalho totalmente inovador e com grande rigor científico na estrutura de todo o desenvolvimento de avaliação e prescrição de treinamento para os atletas paraolímpicos nacionais.

Acredito que o trabalho desenvolvido por essa equipe multidisciplinar e que contou com a participação de diversas universidades brasileiras, foi uma das avaliações de atletas mais criteriosas já realizadas em território nacional, passando desde critérios simples de avaliações Antropométricas até as avaliações mais sofisticadas e de alto custo financeiro, bem como, com a preocupação do desenvolvimento da adaptação ao fuso horário de Sidney e do rendimento esportivo dos atletas durante o período de treinamento.

Assim, visualizo a necessidade de manter e implementar tal trabalho, junto ao CPB e em outras instituições que busquem essa qualidade na planificação de seus macrocilos de treinamento.

Desta forma, tenho não somente à agradecer a todos os meus colegas de trabalho, bem como, a RBME e ao CPB que não só acreditaram mas participaram efetivamente de todo o projeto de avaliação dos atletas paraolímpicos. Agradeço também a todos os atletas paraolímpicos que participaram e ou não dos jogos de Sidney, pois a contribuição desses atletas foi de suma importância para o sucesso de todo o nosso trabalho.

Esse número da RBME busca demonstrar os métodos utilizados e os resultados obtidos em todas as avaliações realizadas e que aqui estão sendo apresentados em 10 artigos científicos (Avaliação Clínica e Médica; Avaliação Cardiológica, Avaliação e Adaptação do Cronotipo e dos Distúrbios do Sono; Avaliação Antropométrica; Avaliação Psicológica do Esporte; Ergoespirométria; Lactato Sanguíneo; Avaliação Isocinética, Avaliação Biomecânica e os Resultados obtidos nos jogos paraolímpicos).

Assim espero que esse número da RBME possa contribuir com todos aqueles que pretendem e ou já trabalham com avaliação desportiva e ou na área do esporte para Pessoas Portadoras de Necessidades Especiais.

Saudações Paraolímpicas

Prof. Dr. Marco Túlio de Mello

Coordenador da Equipe de Avaliação dos Atletas Paraolímpicos/Sydney 2000

Editor Convidado RBME 